\title{
Choice Between Domestic and Foreign Debt: A Case Study of Pakistan
}

\author{
Ghazala Zafar Lashari ${ }^{1}$, Muhammad Akbar ${ }^{2}$, Ruhma Khan ${ }^{3}$ \\ ${ }^{1}$ Department of Economics, Women University of Azad Jammu and Kashmir Bagh, Bagh, Pakistan \\ ${ }^{2}$ Department of Economics, Bahauddin Zakariya University, Multan, Pakistan \\ ${ }^{3}$ Institute of Management Sciences, Bahauddin Zakariya University, Multan, Pakistan
}

\section{Email address:}

Ghazalalashari.11@gmail.com (G. Z. Lashari)

\author{
To cite this article: \\ Ghazala Zafar Lashari, Muhammad Akbar, Ruhma Khan. Choice Between Domestic and Foreign Debt: A Case Study of Pakistan. \\ International Journal of Economics, Finance and Management Sciences. Vol. 5, No. 6, 2017, pp. 284-293. \\ doi: $10.11648 /$ j.ijefm.20170506.12
}

Received: July 28, 2017; Accepted: August 8, 2017; Published: November 15, 2017

\begin{abstract}
In Pakistan, domestic debt, foreign debt and debt servicing is the most discussed issue among the economists and policy makers. Pakistan has been taking a substantial amount of money in the form of domestic and foreign debt since 1970's. Most common reason of debt dependency is saving-investment gap and revenue-expenditure gap. To fill these gaps, debts has become a common source. High level of debt servicing left no room for policy makers to carry out macroeconomic reforms in order to increase GDP growth rate. The present study has been conducted to investigate the choice between domestic and foreign debt in promoting economic growth. Auto regressive Distributed Lag (ARDL) approach has been used in the study for the data set from 1972-2010. It is found that both foreign and domestic debt servicing have negatively influenced the economic growth. In the light of the findings of this study, it is suggested that Pakistan should not rely on both external and internal debts to fulfill its gaps. Policy makers should use the policy of maximum revenue generation through domestic resource utilization, divert public expenditure from consumption to investment, promote tax culture and investment in human capital is much needed to reduce dependence on debts.
\end{abstract}

Keywords: Domestic Debt, Foreign Debt, Debt Servicing, Real GDP, ARDL

\section{Introduction}

For the achievement of the targets of economic and social development, the governments of emerging economies have to face a lot of challenges. As the scenario is made complicated by unstable socio-political background internally, an increasingly globalize international economic environment gives a meaning of greater amount of exposure to external shocks. A greater emphasis is put on financing of government operations, keeping in view of demands placed by these shocks, and ensuring a sustainable level of growth and appropriate safety for vulnerable section of society. Therefore, financing mechanism of developing countries is considered important for $\mathrm{debt}^{1}$ creating flows. It is quite

1 The words credit, finance and loan can interchangeably used for debt. Debt means using funds of someone else with an agreement to be paid back in future with or without interest. Debt involves two parties; lender and borrower. natural that countries devise their economic policies so that maximal level of economic stabilization and growth can be achieved. Accordingly (Kirkpatrick, 2000; Ogiriki \& W. Priye, 2014) have proved in their studies that financial system is sin qua non for economic growth and poverty reduction. This has been discussed a lot in the literature that domestic and foreign debts are dampening down the economic growth (Atique \& Malik, 2012; Rais \& Anwar, 2012; Shah \& Parvin, 2012). But there is a little discussion about the choice of these debts. This study has the significance as it incorporates both types of debt simultaneously to explore the nature of relationship between domestic debt, foreign debt and economic growth of Pakistan.

This is the common characteristic of the developing countries like Pakistan that they are in the debt trap and some of them also facing the problem of debt overhang ${ }^{2}$. In

2 It is the situation in which a country is unable to pay its liabilities. 
Pakistan, domestic debt, foreign debt and debt servicing is the most discussed issue among the economists and policy makers. Pakistan has been taking a substantial amount of money in the form of domestic and foreign debt since 1970's. Most common reason of debt dependency is savinginvestment gap and revenue-expenditure gap. To fill these gaps, debts have become a common source of financing. But after all, repayments of the debts create the pressure on budget. Governments of less developed countries have to allocate a lot of resources for the debt servicing ${ }^{3}$ of internal and external debts. Debt servicing creates the deficit in the budget and in turn governments have to borrow more to finance the budget deficits ${ }^{4}$. This creates many issues like poverty, unemployment, inflation and particularly decline of economic growth in the economy.

The goal of financing is the pooling up of resources by considering the cost and risk attached with each type of financing along with macroeconomic and monetary implications.

The costs attached with domestic debt are crowding out of private investment, inflation escalation and fall in economic growth (Sheikh et al., 2010). Similarly, if the government adopts the foreign debt then exchange rate risk, poverty and growth dampening etc. can happen.

For filling gaps, government uses public debts as a vital tool. Economic growth can be increased with efficient use of public debt and public debt also help government for the attainment of development and other objectives. A country needs financing for development related projects, for enhancing production capacity and accelerating economic growth. In case of mismanagement of public debts, it becomes a nuisance for the economy causing the sluggishness in economic growth, macroeconomic instability, high unemployment, decreasing growth rate, increasing inflation rate and crowding out of investment. In Pakistan, macroeconomic consequences of high level of public debts due to cumulative effect of growing budget deficits and associated needs for borrowing are being growly recognized now. Recently debt and liabilities in 2010 is $72.3 \%$ of GDP according to annual report of $\mathrm{SBP}^{5}$. Resultantly social development programs have been shrinking. In reality if a country is suffering from debt trap it leads to large borrowings adding to debt stock and thus a vicious cycle of debt trap is initiated. This results in high expending growth of debt and budget deficits creating fundamental macroeconomic instability (Singh 2014, p 586)

Public Debts are categorized into domestic debt and foreign debt. The government's borrowing entails cost risk associated with the borrowing and the objective is to minimize the overall cost in the economy. Budget deficit can be financed by seigniorage.

\footnotetext{
3 Debt servicing means repayment of the principal payment plus interest payments on the principal payments amounts.

4 To finance the deficit of budget, governments can borrow internally or externally along with the use of foreign exchange reserves and printing of new money. Each and every method of these has its own merits and demerits.

5 Source of date is Sate Bank of Pakistan Annual Report 2011-12
}

Seigniorage is the direct way of financing budget deficit. The direct cost is low but risks are considerable. Monetary financing creates more aggregate demand that increase the price level in the economy. If domestic borrowing is financed by central bank, it increases inflationary pressure. (Jebran et al., 2016; Wani \& Kabir, 2016; Matiti, 2013) observed in their studies that domestic debt has a crowding-out effect due to increase in rate of interest and foreign debt has no crowding-out effect. After receiving the foreign debt, interest rate on foreign debt is relatively less than domestic debt, thus it encourages private investment

\section{Theoretical Framework}

This section explained the theoretical framework regarding domestic and foreign debt focusing on economic growth. The theory of debt suggests that it can influence the economic growth both positively and negatively. There are two main theories regarding the debt and growth nexus:

(i) Traditional Theory

(ii) Ricardian Equivalence Theory

Both the theories have opposite views. According to the traditional theory, if the government adopts tax reduction policy, it can have different impacts on an economy. The tax cut would increase consumer spending and demand for goods and services both in the short run and long run. Consumers feel wealthier themselves in the short run and thus increase their spending, which increase demand for goods leading to rise in output and employment level. In this case, marginal propensity to save is less than the marginal propensity to consume. Due to reduced savings at an individual level, public savings level also retards. Therefore, high return on capital i.e. real interest rate encourages foreign capital in the country. Besides, another impact of high real interest rate is that it crowds out private investment. The low investment level leads to lower output, so in long run total output will be low and as a result lower consumption and economic welfare. Consequently tax cut would be burden on next generation (Patinkin and Chandrasekhar, 1965).

According to Ricardian equivalence theory, the consumers are rational and forward looking. A debt-financed is equivalent to future tax and consumer does not change his current consumption pattern, consumer saves extra disposable income in order to pay the future tax liability (Barro, 1974). Therefore, there is parity between fall in public savings and rise in private savings. Under the environment of unchanged gross savings, the other macroeconomic variables such as interest rate, investment and national income level remain the same.

There are multiple ways through which foreign debt and debt servicing can influence economic growth especially through investment. Foreign debt is mostly used to bridge gap between savings and investment and foreign debt boosts growth rate though investment channel (Chenery and Strout, 1966).

The second channel through which foreign debt affects growth rate is allocation of resources and production skills. It 
is needless to mention that foreign debt enters in economy through public sector so it can be envisaged that foreign debt has positive as well as negative effects on efficacy and productivity. Donors always attach several conditions which can be detrimental for economic performance.

The theory of debt cycle provides comprehensive insight on the role of foreign debt on economic growth in the recipient countries.

\section{Review of Literature}

Beaugrand et al. (2002) empirically examine the role of domestic and foreign debt regarding deficit financing in western and central African nations. The study applied simple analytical framework for choice between domestic and external debt. The findings show that highly concessional foreign debt is superior choice than costly domestic debt. The study explains macroeconomic aspects of choice between external and domestic debt in the context of two views. The study finds that according to traditional view government deficit has large impact on economy especially on private investment and external current accounts. The study concludes that these countries should take domestic debt for financing budget deficit.

Kohlchen (2009) empirically analyze the domestic versus foreign debt servicing for 53 countries over the period of 1980-2005. The study shows that the default rates are $3.90 \%$ of external debt and $1.65 \%$ internal debt in a given time period. The study finds that the both type of defaults are explain by the model of limited independent and dependent which shows that domestic debt defaults are lower than external defaults. The analysis reveals that domestic creditors have lesser leverage than their international counterparts in financial institutes.

Muhadi and Saski (2009) explore the role of domestic and foreign debt in Indonesia. The study applied OLS technique on annual data over the period of 1991-2006. The study finds that foreign debt as fundamental policy to alleviate deficit. The study examine that foreign debt positively affect investment and economic growth. The analysis shows negative effects of external debt repayment on external debt currency reserves. Investment is negatively influenced by domestic debt due to its crowding out effects by slashing stock of capital and production. It concludes that domestic debt is costly than external debt in Indonesia.

Similarly Amassoma (2011) examines nature of causality among domestic and foreign debt and economic growth in Nigeria.The Vector autoregressive (VAR) and Vector Error Correction (VEC) models on annual data over the period of 1970-2009 are applied. The findings of VAR model show that bi-directional causality between domestic debt and growth. The VEC model reveals unidirectional causality. It is recommended that government should depend on domestic debt in motivating growth instead of external debt.

Efthimiadis and Tsintzos (2011) also contributed in the literature by analyzing effects of domestic-external debt ratio on economic growth. Decentralized model of endogenous economic growth is used to show that increase in domesticexternal debt ratio result in increases of the public to private capital ratio which in turn affects positively the long run economic growth. It is suggested that switches from external debt to domestic debt guide to a reduction of capital outflows. The analysis of this study investigates that savings are reinvested indirectly for public capital by household and directly for private capital which lead to increase the economic growth. The study explores that increase in internal debt also increase the transition.

Iqbal et al., (2015) investigate the link between foreign trade and foreign debt on economic growth of Pakistan by using time series data from 1972 -2013 with help of OLS technique. The findings are that foreign debt and export has positive and significant effect with sound macroeconomic policies. But this study has found no significant impact of imports on economic growth of Pakistan.

Shahzad and Javid (2015) examined the relationship of foreign debt on investment and productivity of Asian Countries by using over the period 1984-2007. It is concluded that foreign debts adversely affect the investment and productivity of the Asian developing countries. On the other hand trade openness and population growth accelerated the economic growth of selected countries. It is concluded minimum debt dependency policies should be adopted for rapid economic growth.

After reviewing the various empirical studies, we can conclude that public debts are important for many macroeconomic indicators such as investment, saving, inflation, gross fixed capital formation, workers' remittances and consumption etc and mounting up economic growth.

\section{Econometric Specification}

In line with above discussion the functional form of the model can be written as:

$$
\begin{aligned}
& G D P=f(D D, L F, R E M, G F C F) \\
& G D P=f(D D S, L F, R E M, G F C F) \\
& G D P=f(E D, L F, R E M, G F C F) \\
& G D P=f(E D S, L F, R E M, G F C F)
\end{aligned}
$$

Where

GDP $=$ Gross Domestic Product

$\mathrm{DD}=$ Domestic Debt

$\mathrm{LF}=$ Labour Force

$\mathrm{GFCF}=$ Gross Fixed Capital Formation

$\mathrm{ED}=$ External Debt

DDS $=$ Domestic Debt Servicing

EDS $=$ External Debt Servicing

REM $=$ Worker Remittances

The present study based on time series data from 19722010. The data sources are Handbook of Statistics on Pakistan Economy, State Bank of Pakistan and Ministry of Finance.

All variables are converted from U.S dollar into Pakistan 
currency by means of $\$$ exchange rates and then deflated by GDP deflator to find inflation adjusted and real variables. Finally $\log$ of all variables are taken.

For time series data first step is to check the stationarity of all variables. Stationarity means that the mean, variance and covariance must be the same over the time period. In order to check stationarity of all series of the variables Augmented Dickey Fuller (ADF) test has been used. This study has analyzed eight variables. GDP is used as dependent variable and REM, GFCF, ED, EDS, DD, DDS and LF are used as explanatory variables. The Result of ADF test is given in table 1.

Table 1. Results of ADF Test.

\begin{tabular}{llll}
\hline Variables & ADF (At level) & $\begin{array}{l}\text { ADF (At First } \\
\text { Difference) }\end{array}$ & $\begin{array}{l}\text { Order of } \\
\text { Integration }\end{array}$ \\
\hline LF & 1.250 & -8.889 & $\mathrm{I}(1)$ \\
GDP & -2.183 & -4.495 & $\mathrm{I}(1)$ \\
GFCF & -2.980 & -6.494 & $\mathrm{I}(0)$ \\
REM & -1.725 & -4.717 & $\mathrm{I}(1)$ \\
ED & -1.810 & -9.473 & $\mathrm{I}(1)$ \\
EDS & -3.591 & -6.258 & $\mathrm{I}(0)$ \\
DD & -1.4329 & -6.993 & $\mathrm{I}(1)$ \\
DDS & -0.161 & -4.584 & $\mathrm{I}(1)$ \\
\hline
\end{tabular}

Source: Author's calculations

Results of the ADF test reveal that the variables of GFCF and EDS are stationary at the level and the variables LF,
GDP, REM, ED, DD and DDS are stationary at first difference. The result of ADF test suggests that AutoRegressive Distributed Lag (ARDL) Approach is appropriate for this study. See appendix for details of ARDL.

\subsection{Bounds Testing Procedure}

Before estimating the long run estimators and Error Correction Model it is important to investigate existence of long run relationship. Ordinary Least Square (OLS) method is employed to find the F-values/Wald-test for the joint significance of the estimators. The Null Hypothesis is defined as:

$$
\begin{gathered}
H_{0}: \beta=\beta_{2}=\beta_{3}=\beta_{4}=\beta_{5}=0 \text { (No co integration) } \\
H_{1}: \beta \neq \beta_{2} \neq \beta_{3} \neq \beta_{4} \neq \beta_{5} \neq 0 \text { (Co integration) }
\end{gathered}
$$

Null hypothesis exhibits no long run relationship exist and alternative hypothesis shows long run relationship exist.. If $\mathrm{F}$-value is greater than upper bound critical value then long run relationship exists and null hypothesis rejected. If Fvalue is less then lower bound critical value than long run relationship does not exist and null hypothesis accepted. If $\mathrm{F}$ value lies between lower and upper bound critical value then test is indecisive.

If long run relationship exists the estimators can be estimated by following equation.

$$
\begin{array}{r}
\Delta \ln (G D P) t=a_{0}+\sum_{t=1}^{p 1}\left(\lambda_{1 i} \Delta \ln (\mathrm{GDP}) \mathrm{t}-\mathrm{i}+\beta 1 \ln (\mathrm{GDP}) \mathrm{t}-1+\sum_{t=1}^{p 2}\left(\lambda_{2 i} \Delta \ln (\mathrm{REM}) \mathrm{t}-\mathrm{i}+\beta 2 \ln (\mathrm{REM}) \mathrm{t}-1 \sum_{t=1}^{p 3}\left(\lambda_{3 i} \Delta \ln (\mathrm{GFCF}) \mathrm{t}-\mathrm{i}+\right.\right.\right. \\
\beta 3 \ln (\mathrm{GFCF}) \mathrm{t}-1++\sum_{t=1}^{p 4}\left(\lambda_{4 i} \Delta \ln (\mathrm{LF}) \mathrm{t}-\mathrm{i}+\beta 4 \ln (\mathrm{LF}) \mathrm{t}-1+\sum_{t=1}^{p 5}\left(\lambda_{5 i} \Delta \ln (\mathrm{ED}) \mathrm{t}-\mathrm{i}+\beta 5 \ln (\mathrm{ED}) \mathrm{t}-1+\varepsilon_{t}(5)\right.\right.
\end{array}
$$

Where LF is labor force, ED is real external debt, GDP is real gross domestic product, REM is workers' remittances, and GFCF is real Gross fixed capital formation.

$$
\begin{array}{r}
\Delta \ln (G D P) t=a_{0}+\sum_{t=1}^{p 1}\left(\lambda_{1 i} \Delta \ln (\mathrm{GDP}) \mathrm{t}-\mathrm{i}+\beta 1 \ln (\mathrm{GDP}) \mathrm{t}-1+\sum_{t=1}^{p 2}\left(\lambda_{2 i} \Delta \ln (\mathrm{REM}) \mathrm{t}-\mathrm{i}+\beta 2 \ln (\mathrm{REM}) \mathrm{t}-1 \sum_{t=1}^{p 3}\left(\lambda_{3 i} \Delta \ln (\mathrm{GFCF}) \mathrm{t}-\mathrm{i}+\right.\right.\right. \\
\\
\beta 3 \ln (\mathrm{GFCF}) \mathrm{t}-1++\sum_{t=1}^{p 4}\left(\lambda_{4 i} \Delta \ln (\mathrm{LF}) \mathrm{t}-\mathrm{i}+\beta 4 \ln (\mathrm{LF}) \mathrm{t}-1+\sum_{t=1}^{p 5}\left(\lambda_{5 i} \Delta \ln (\mathrm{EDS}) \mathrm{t}-\mathrm{i}+\beta 5 \ln (\mathrm{EDS}) \mathrm{t}-1+\varepsilon_{t}(6)\right.\right.
\end{array}
$$

The other variables are same but real external debt servicing is replaced by real external debt. Similarly, growth equation has been tested by domestic debt model

$$
\begin{array}{r}
\Delta \ln (G D P) t=a_{0}+\sum_{t=1}^{p 1}\left(\lambda_{1 i} \Delta \ln (\mathrm{GDP}) \mathrm{t}-\mathrm{i}+\beta 1 \ln (\mathrm{GDP}) \mathrm{t}-1+\sum_{t=1}^{p 2}\left(\lambda_{2 i} \Delta \ln (\mathrm{REM}) \mathrm{t}-\mathrm{i}+\beta 2 \ln (\mathrm{REM}) \mathrm{t}-1 \sum_{t=1}^{p 3}\left(\lambda_{3 i} \Delta \ln (\mathrm{GFCF}) \mathrm{t}-\mathrm{i}+\right.\right.\right. \\
\beta 3 \ln (\mathrm{GFCF}) \mathrm{t}-1++\sum_{t=1}^{p 4}\left(\lambda_{4 i} \Delta \ln (\mathrm{LF}) \mathrm{t}-\mathrm{i}+\beta 4 \ln (\mathrm{LF}) \mathrm{t}-1+\sum_{t=1}^{p 5}\left(\lambda_{5 i} \Delta \ln (\mathrm{DD}) \mathrm{t}-\mathrm{i}+\beta 5 \ln (\mathrm{DD}) \mathrm{t}-1+\varepsilon_{t}(7)\right.\right.
\end{array}
$$

Where GDP, REM, GFCF, DD, LF are real gross domestic product, workers' remittances, real gross fixed capital formation, real domestic debt and labor force.

$$
\begin{aligned}
\Delta \ln (G D P) t=a_{0}+ & \sum_{t=1}^{p 1}\left(\lambda_{1 i} \Delta \ln (\mathrm{GDP}) \mathrm{t}-\mathrm{i}+\beta 1 \ln (\mathrm{GDP}) \mathrm{t}-1+\sum_{t=1}^{p 2}\left(\lambda_{2 i} \Delta \ln (\mathrm{REM}) \mathrm{t}-\mathrm{i}+\beta 2 \ln (\mathrm{REM}) \mathrm{t}-1 \sum_{t=1}^{p 3}\left(\lambda_{3 i} \Delta \ln (\mathrm{GFCF}) \mathrm{t}-\mathrm{i}+\right.\right.\right. \\
& \beta 3 \ln (\mathrm{GFCF}) \mathrm{t}-1++\sum_{t=1}^{p 4}\left(\lambda_{4 i} \Delta \ln (\mathrm{LF}) \mathrm{t}-\mathrm{i}+\beta 4 \ln (\mathrm{LF}) \mathrm{t}-1+\sum_{t=1}^{p 5}\left(\lambda_{5 i} \Delta \ln (\mathrm{DDS}) \mathrm{t}-\mathrm{i}+\beta 5 \ln (\mathrm{DDS}) \mathrm{t}-1+\varepsilon_{t}(8)\right.\right.
\end{aligned}
$$

All variables are same as in equation (7) except real domestic debt DD) is replaced by real domestic debt servicing (DDS).

\subsection{Co Integration and Error Correction Mechanism (ECM) Using ARDL Technique}

If $F$ value of joint significance is outside the critical values, the long-run coefficients and associated error correction mechanism will be estimated. Error correction mechanism is famous for the followings:

(i) ECM measures the correction of prior period disequilibrium having good economic implications.

(ii) ECM is constructed in terms of first difference for removal of trends from variables and the problem of 
spurious regression is resolved.

(iii) ECM fits to econometric modeling ranging from general to specific which best fits the data set.

(iv) It is a fact that disequilibrium error term is a stationary variable. The variables are co-integrated so there is an adjustment process preventing the error in long run.

\section{Results and Discussion}

\section{Bounds Test for Co Integration}

First of all the long-run relationship is checked and for this Bounds test for co integration is applied and the results of test have been displayed in table 2
The first column describes the equation specifying dependent variable and independent variables. GDP is taken as dependent variable and REM, GFCF, ED and LF have been taken as independent variables. In the second column Fstatistic based on Wald test has been given. In the third column, upper bound values have been given. Every equation is tested to discover the long run relationship. For this purpose it is estimated the F-statistic based on Wald test and compare the computed value with critical values (with intercept or time trend) given in Pesaran et al. (1999). For the existence of long run relationship F-statistic should be greater than upper bond value.

Table 2. Results of Bounds Test for Co integration.

\begin{tabular}{llll}
\hline Equations & F-statistic & Upper Bound Critical value & Conclusion \\
\hline i) GDP/REM, GFCF, ED, LF & 4.87 & $4.49(97.5 \%)$ & Co integration \\
ii) GDP/REM, GFCF, EDS, LF & 3.68 & $3.52(90 \%)$ & Co integration \\
iii) GDP/REM, GFCF, DD, LF & 5.87 & $5.06(99 \%)$ & Co integration \\
iv) GDP/REM, GFCF, DDS, LF & 8.64 & $5.06(99 \%)$ & Co integration \\
\hline
\end{tabular}

Source: Author's calculations

The value of F-statistic calculated for real external debt is 4.87 and it is more than upper bound critical value. Hence long run relationship exists in the first equation. The same process has been repeated for the second equation that is for real external debt servicing and estimated the value of Fstatistic that is 3.68. This value is again greater than upper bound value showing the co-integration. Similarly the computed value of real domestic debt and real domestic debt servicing are 5.87 and 8.64 respectively which are more than the upper bound value.

\section{Long Run Results for Foreign Debt}

The impact of foreign debt on growth is analyzed by using time series data for the period of 1972-2010 is used. All specified variables are inflation adjusted. The methodology employed is ARDL. Table 3 displayed the long run results for the foreign debt.

In equation (1) five variables have specified. Real GDP is dependent variable and it is used to measure the economic growth. The explanatory variables are labor force, real gross fixed capital formation, real remittances, real external debt and real external debt. All variables are in the logarithmic form. It is hypothesized that all the explanatory variables should have positive sign except labor force.

Table 3. Long- Run Results of Foreign Debt on Economic Growth.

\begin{tabular}{llll}
\hline Dependent Variable: GDP SBC $(\mathbf{0 , 1 , 0 , 0 , 0 , 0 , 0 , 0 , 0 )}$ \\
\hline Independent Variables & Coefficients & Standard Error & t-statistic \\
\hline REM & 0.078 & 0.0100 & 7.784 \\
GFCF & 0.159 & 0.032 & 4.860 \\
LF & -0.409 & 0.179 & -2.277 \\
ED & 0.156 & 0.027 & 5.581 \\
C & 3.406 & 0.342 & 9.934 \\
T & 0.018 & 0.0026 & 6.944 \\
\hline
\end{tabular}

Source: Author's calculations
From the Table 3 it can be observed that the parameter of worker remittances is positive having the value .078 and highly statistically significant. The value of the parameter suggests that $1 \%$ increase in remittances would increase GDP by 7.8 percent. There are many channels through which workers' remittances can influence the economic growth positively.

The foremost channel is the expansion of household resources. In fact, due to an increase in workers' remittances, household can reduce the reliance on credit and can increase the investment level which can lead to economic growth (Young, 2002; Woodruff and Zenteno, 2004).

Secondly, remittances of workers are a source of foreign exchange which helps for achievement of higher economic growth through reduction in external debt and current account deficit. Without sustainable level of workers' remittances the real output growth in Pakistan cannot be achieved [Iqbal and Sattar, 2005].

Thirdly, workers' remittances can reduce the inequality and poverty by providing the money and goods to households that would enhance their welfare. At country level, these can be used for financing the consumption expenditure and for small business so that income can be increased by multiplier. Remittances also play a central role in balance of payments for reducing unemployment through migration of labor abroad. Therefore, remittances positively contribute in economic growth (Faridi et al., 2015).

The inflow of remittances enhances the economic growth by reducing the poverty after increasing the income of recipient's countries. It increases growth by increasing the access towards health facilities and better education (Calaro, 2008; Jongwanich, 2007; Taylor 1992; Stark and Lucas, 1988).

The second variable is real gross capital formation which is used as proxy for investment. The value of this parameter 
is 0.159 showing that 1 percent addition in gross capital formation results in 15 percent increase in the GDP. This effect is highly significant and strong. Investment influences economic growth through a number of ways. In LDCs, investment in infrastructure is vital for development as producers can increase the productive capacity by using the modern technology.

The expansion of infrastructure directly boosts activities which are productive. On the other hand, investment in education and training develop human resource. (Najid and Ahmad, 2012) suggested that numbers of teachers should be increased at primary level for the development. Agricultural research and extension services also increase productive abilities of a country. Investment in human capital enhances the cost of raising children decrease fertility therefore, increase saving per-person which raise the per-capita growth (Barro, 1991). Many studies (Blomstrom et al., 1996; Khan and Reinhart, 1990; Otani \&Villanueva 1996) found positive relationship between investment and growth. Government should invest more on education as it is vital for economic growth.

Coefficient of labor force is -0.409 . It means that one percent increase in labor force lowers the GDP by 40 percent. The parameter is statistically highly significant. If labor force is uneducated, unskilled and untrained, it means that it would not contribute in economic growth so effectively.

In Nigeria, literacy rate is low and most of the workers cannot make use of technical machinery. Their methods of production are not technical, so their marginal productivity is very low resultantly real income, savings, investment and output is slashed (Johnson, 2011).

Now turn to more concerned variable that is real external debt. The value of this parameter is 0.15 . It is positive and highly statistically significant. It suggests that one percent rise in real external debt increases the RGDP by 15 percent. Growth is positively related with foreign debt especially if government uses this tool for projects like education, health, production and distribution of power, infrastructure, and agriculture sectors. The result is in line with other studies like (Rais \&Tanzeela, 2010).

\section{Error Correction Estimating Results for Foreign Debt}

Table 4 interprets the short run results computed from the unrestricted error correction model (UECM). dGDP is a dependent variable which shows the first difference of the variable. Short run and long run values of coefficients are different. The signs have remained the same but the significance level has been changed for some variables. Three variables i.e. workers' remittances, labor force and external debt were highly significant in the long-run but in error correction results of these variables have become insignificant.

The error correction term shows adjustment speed for restoration of equilibrium and shows whether this speed is fast or slow. This term should be negative and statistically significant. Here ECM is equal to -0.557 meaning that adjustment speed is more than half within one year.
Table 4. Short Run Results of Foreign Debt on Economic Growth.

\begin{tabular}{|c|c|c|c|}
\hline \multicolumn{4}{|c|}{ Dependent Variable: dGDPSBC $(0,1,0,0,0,0,0,0,0)$} \\
\hline Independent Variables & Coefficients & Standard Error & t-statistic \\
\hline dREM & 0.008 & 0.010 & 0.791 \\
\hline dREM1 & 0.036 & 0.009 & 3.651 \\
\hline dGFCF & 0.089 & 0.019 & 4.624 \\
\hline dLF & -0.914 & 0.086 & -1.055 \\
\hline dED & 0.033 & 0.029 & 1.144 \\
\hline $\mathrm{dC}$ & 1.998 & 0.351 & 5.39 \\
\hline $\mathrm{dT}$ & 0.010 & 0.002 & 4.607 \\
\hline $\operatorname{ecm}(-1)$ & -0.557 & 0.084 & -6.628 \\
\hline
\end{tabular}

Source: Author's calculations

\section{Long Run Results for Foreign Debt Servicing}

From the Table 5, it can be seen that the parameter of worker remittances is positive and highly significant. The value of the coefficient is 0.090 which indicates that if worker remittances increase by one percent then GDP by 9 percent. In fact, remittances develop a country's creditworthiness by increasing the access in foreign capital markets. World Bank (2006) claimed that the credit rating of a country improves due to more remittances.

In this way, the human and physical capital of a country increases which lead to economic growth. The next parameter is gross capital formation that is positive and strongly significant. The value of the parameter is 0.181 suggesting that one percent rise in gross capital formation increases the GDP by 18 percent.

Another variable is labor force which has the value of 0.843. It means that one percent increase in labor force results 84 percent fall in GDP which is negative and statistically significant.

Table 5. Long-Run Results of Foreign Debt Servicing on Economic Growth.

\begin{tabular}{llll}
\hline Dependent Variable: GDP SBC $(\mathbf{0 , 1 , 0 , 0 , 0 , 0 , 0 , 0 , 0 )}$ & \\
\hline Independent Variables & Coefficients & Standard Error & t-statistic \\
\hline REM & .090360 & .013149 & 6.8722 \\
GFCF & .18184 & .047117 & 3.8593 \\
LF & -.84364 & .22296 & -3.7834 \\
EDS & -.026177 & .016169 & -1.6190 \\
C & 4.4349 & .33843 & 13.1043 \\
T & 0.24970 & .0028983 & 8.6154 \\
\hline
\end{tabular}

Source: Author's calculations

Now turn to more focused variable that is external debt servicing. The value of this coefficient is 0.261 . It is indicating that GDP will decrease by 26 percent if external debt servicing increases by one percent.

The negative relationship between external debt servicing and growth is due to the following reasons: Firstly, debt servicing stashes stock of foreign exchange reserves as well as capital flow. Secondly, debt overhang erodes creditworthiness. Thirdly, reduction in imports for accumulating the foreign exchange reserves for debt servicing and this creates the problems in international (Hameed et al., 2008; Malik et al., 2010) also found the negative relation between external debt servicing and GDP.

Error Correction Estimating Results for Foreign Debt Servicing 
Table 6 interprets the short-run results. Table 6 shows that the signs of short-run and long-run parameters are the same. The error correction term is again negative and statistically significant.

Table 6. Short Run Results of Foreign Debt servicing on Economic Growth.

\begin{tabular}{llll}
\hline Dependent Variable: & dGDPSBC & $(\mathbf{0 , 1 , 0 , 0 , 0 , 0 , 0 , 0 , 0 )}$ & \\
\hline Independent Variable & Coefficients & Standard Error & t-statistic \\
\hline dREM & 0.014 & 0.011 & 1.263 \\
dREM1 & 0.029 & 0.011 & 2.635 \\
dGFCF & 0.077 & -0.020 & 3.795 \\
dLF & -0.207 & 0.089 & -2.328 \\
dEDS & -0.011 & 0.007 & -1.433 \\
dC & 1.887 & 0.355 & 5.302 \\
dT & 0.010 & 0.002 & 4.678 \\
ecm(-1) & -0.425 & 0.071 & -5.934 \\
\hline
\end{tabular}

Source: Author's calculations

\section{Long Run Results for Domestic Debt}

Table 7 shows the estimated result of equation (4). The coefficient of real worker remittances is 0.17 . It is indicating that one percent increase in worker remittances enhances the GDP by 17 percent. Thus, remittances have positively contributed in economic growth. The inflow of remittances decrease the incidence of poverty by increase the income level of the people of recipients' countries which leads to increase the economic growth. Moreover, remittances enhance growth through having more access towards education and health services. This result is in line with other studies like (Calaro, 2008; Jongwanich, 2007; Stark and Lucas, 1988).

Table 7. Long- Run Results of Domestic Debt on Economic Growth.

\begin{tabular}{llll}
\hline Dependent Variable: GDP SBC $(\mathbf{0 , 1 , 0 , 0 , 0 , 0 , 0 , 0 ,})$ & \\
\hline Independent Variable & Coefficients & Standard Error & t-statistic \\
\hline REM & 0.171 & 0.063 & 2.689 \\
GFCF & 0.194 & 0.109 & 1.769 \\
LF & 0.638 & 0.173 & 3.685 \\
DD & 0.204 & 0.056 & 3.617 \\
C & 1.673 & 0.107 & 15.602 \\
\hline
\end{tabular}

Source: Author's calculations

The next parameter is gross capital formation that is also found positive. The value of the coefficient is 0.194 . It is suggesting that one percent addition in gross capital formation increases the GDP by 19 percent.

Third parameter is labour force. The value of labor force 0.63 which is positive and statistically significant. It shows that the one percent increases in labor force, increases GDP by 63 percent. Labor force influences the growth positively as human capital formation is method of improving labour skills and abilities that enhance the labour productivity and accelerate economic growth. Investment in Human capital is more productive than physical capital. This result is in line with other studies like (Haribison, 1962; Schultz, 1992; Mincer, 1958; Johnson, 2000)

Now we discuss the core variable of equation (4) that is real domestic debt. The value of the parameter of real domestic debt is 0.204 . It is positive and highly significant. It shows that 1 percent raise in domestic debt adds the GDP value by 20 percent. The reason of this positive relationship may be that domestic debt (market-based) generates more stability in macroeconomic activity. It protects from monetary shocks and sudden changes in exchange rate. Therefore, domestic debt impacts the GDP positively. Maana et al. (2008) found the positive association between domestic debt and economic growth. Abbas and Christensen (2007) also discovered that domestic debt has influenced the economic growth of less developed countries positively.

Error Correction Results for Domestic Debt

Table 8 exhibits the short-run results. There is a difference in the signs of the variables in the error correction estimating results. For example the sign of domestic debt is negative in the short run. The value of domestic debt parameter is -0.056 which shows that one percent increase in domestic debt decreases GDP by 5 percent. The reason of negative relationship is that when government borrows domestically, it uses domestic savings. Hence funds for private lending are reduced. When there will be fewer funds, it raises the cost of capital for private borrowers and reduces demand for private investment and growth (Diamond, 1965). So far as, the error correction term is concerned, it is negative and statistically significant. The value of ECM shows the economy will restore its long run equilibrium within a year.

Table 8. Short Run Results of Domestic Debt on Economic Growth.

\begin{tabular}{llll}
\hline Dependent Variable: & dGDP SBC $(\mathbf{0 , 1 , 0 , 0 , 0 , 0 , 0 , 0 ,}$ & \\
\hline Independent Variable & Coefficients & Standard Error & t-statistic \\
\hline GDP1 & -0.263 & 0.148 & -1.770 \\
dREM & 0.003 & 0.011 & 0.340 \\
dGFCF & 0.108 & 0.024 & 4.410 \\
dLF & 0.129 & 0.066 & 1.957 \\
dDD & -0.056 & 0.023 & -2.380 \\
dDD1 & -0.040 & 0.021 & -1.839 \\
dC & 0.340 & 0.102 & 3.308 \\
ecm $(-1)$ & -0.203 & 0.0662 & -3.664 \\
\hline
\end{tabular}

Source: Author's calculations

\section{Long Run Results for Domestic Debt Servicing}

Table 9 elaborated the estimation of equation (5). The coefficient value of worker remittances is 0.129 . It is suggesting that one percent raises in worker remittances increases GDP by 12 percent. This effect is positive but statistically insignificant.

Another variable is gross capital formation. The value of this parameter is 0.350 . It is indicating that one percent increases in real gross capital formation results to raise GDP by 35 percent. This effect is positive and significant. Now, we consider the value of regression coefficient of labor force which is 0.561 . It is exhibiting that the one percent addition in labor force increases in GDP by 56 percent. This effect is also positive and significant. The regression coefficient of real domestic debt servicing is negative and statistically significant. The value of the coefficient is -0.898 . It is showing that one percent increases in real domestic debt servicing decreases real GDP by 89 percent. The possible reason of the negative relationship may be that an increase in 
real domestic debt servicing decreases real GDP due to high cost of borrowing, public and private investment both decrease, so GDP will decrease as well (Sheikh et al., 2010).

Table 9. Long-Run Results of Domestic Debt servicing on Growth.

\begin{tabular}{llll}
\hline Dependent Variable: GDP SBC $\mathbf{( 0 , 1 , 0 , 0 , 0 , 0 , 0 , 0 , 0 )}$ & \\
\hline Independent Variables & Coefficients & Standard Error & t-statistic \\
\hline REM & 0.129 & 0.054 & 2.362 \\
GFCF & 0.350 & 0.098 & 3.563 \\
LF & 0.561 & 0.183 & 3.066 \\
DDS & -0.898 & 0.036 & -2.446 \\
C & 1.876 & 0.135 & 13.848 \\
\hline
\end{tabular}

Source: Author's calculations

\section{Error Correction Results for Domestic Debt Servicing}

Table 10 shows the short run results of equation (5). The signs of coefficients are different in the short run as compare to the long run values. The variable of regression coefficient of domestic debt servicing is again negative. The value of coefficient is 0.189 indicating that one percent increase in real domestic debt servicing decreases real GDP value by 18 percent. The error correction term is found negative and statistically significant. The value of ECM shows the economy will turn to long run stable equilibrium within a year.

Table 10. Short Run Results of Domestic Debt servicing on Economic Growth.

\begin{tabular}{llll}
\hline Dependent Variable: & GDP SBC $(\mathbf{0 , 1 , 0 , 0 , 0 , 0 , 0 , 0 , 0 )}$ & \\
\hline Independent Variables & Coefficients & Standard Error & t-statistic \\
\hline dRREM & -0.015 & 0.010 & -1.471 \\
dGFCF & 0.074 & 0.294 & 2.545 \\
dLF & 0.119 & 0.081 & 1.469 \\
dDDS & -0.189 & 0.015 & -1.205 \\
dDDS1 & -0.520 & 0.014 & -3.596 \\
dC & 0.401 & 0.181 & 2.215 \\
ecm(-1) & -0.213 & 0.091 & -2.328 \\
\hline
\end{tabular}

Source: Author's calculations

\section{Conclusion and Recommendations}

This study has been planned to determine the choice between the two types of public debt i.e. domestic debt and foreign debt using time series data from 1972 to 2010 applying the Autoregressive Distributed Lag (ARDL) technique for finding the short run and long run results.

The objective of this study is to dig out whether domestic or foreign debt suits Pakistan's economy by examining the impacts of foreign debt and domestic debt and their respective interest payments on the economic growth of Pakistan.

It is found that external and domestic debt stock influenced the economic growth positively both in the short-run and long-run with the exception of volume of domestic debt in the short-run. The positive relationship between domestic debt and growth may be due to the fact that domestic debt (market-based) generates more stability in macroeconomic activity. This study also found that domestic debt has negative effects on growth in the short-run. This may be due the reason that when government borrows domestically, it uses domestic savings. Hence funds for private lending are reduced. When there will be fewer funds, it raises the cost of capital for private borrowers and reduces demand for private investment and growth.

Further, the impact of foreign and domestic debt servicing on economic growth has also been analyzed. The findings of the study suggest that both foreign and domestic debt servicing have negatively influenced the economic growth. The possible reason of the negative relationship domestic debt servicing and economic growth may be that an increase in real debt servicing decreases GDP due to high cost of borrowing, public and private investment both decreases, so GDP will decrease as well.

So it is concluded from the analysis that both the types of debts are contributing positively in the growth of Pakistan's economy but their interest payments (debt servicing) are worse off for the economy. So, the choice between the domestic debt and foreign debt is based on value of the both coefficients as these have the same sign. The analysis of values of coefficients suggests that while discussing the stock variables, the magnitude of domestic debt is more than the foreign debt. Even both are contributing positively but the value of domestic debt estimator is more positive than foreign aid estimator. Moreover, domestic and foreign debt servicing has inverse relationship with economic growth. Now again we have to choose the domestic debt and foreign debt to see the magnitude of parameter estimated. The results suggest that foreign debt servicing is relatively favorable as compare to domestic debt servicing. On basis of analysis recommendations are made. Government may shed unnecessary mega size of public sector along with reduction in current expenditure. Current expenditure, debts servicing and defense expenditure are major cause of fiscal deficit which force the policy makers to depend on debt. This situation sustain over time and prime cause of debt-trap for the economy of developing countries. Moreover, labour force and worker remittances have positive effect on economic growth. It suggests that investment on human capital increase labour force participation and increase economic growth. Furthermore promote capital formation and revenue generation policies like encouragement of tax culture and industrial sector in order to reduce debt dependency.

\section{Appendix}

Autoregressive Distributed lag (ARDL) Approach Pesearn et al. (1996a) devised the ARDL for estimating short as well as long run relationship among the different variables. In this study, the ARDL has been used due to three reasons:

i) It can be applied if the variables are $\mathrm{I}(0), \mathrm{I}(1)$ or mutually co integrated. Unit root test is required in Johansson approach but not in ARDL.

ii) The methodology is also applicable for the small sample so we have applied ARDL approach due to small sample.

iii) The methodology would not give the better results if 
the variables included in the model are integrated order i.e. I(2).

The ARDL Approach is two-stage methodology. At first, long run relationship among variables is tested through FStatistic. Pesran et al. (1996) gave appropriate critical values for different numbers of regressors. They give two types of critical values in spite of the ARDL model contain intercept or trend. This provides a bound covering all possible classification of variables that are integrated at I (0) or I(1).

If F-Statistic is outside of critical values, there is no need to know whether the variables are $\mathrm{I}(0)$ or $(1)$. The result is inconclusive. If the computed F-Statistic is within the range of critical value bound and depend on whether the underlying variables are $\mathrm{I}(0)$ or $\mathrm{I}(1)$. At this stage unit root tests on the variables are conducted. At the second stage, co-efficient of the long run relation and making inference using ARDL is done.

\section{References}

[1] Abbas, S. M. A. and J. E. Christensen (2007). "The Role of Domestic Debt Markets in Economic Growth: An Empirical Investigation for Low-income Countries and Emerging Markets". IMFW/P 7/27.

[2] Amassoma, D. (2011). "External Debt, Internal Debt and Economic Growth Bound in Nigeria using a Causality Approach." Current Research Journal of Social Sciences 3(4): 320-325.

[3] Atique, R. and K. Malik (2012). "Impact of Domestic and External Debt on the Economic Growth of Pakistan." World Applied Sciences Journal 20(1): 120-129.

[4] Barro, R. J. (1974). "Are Government Bonds Net Wealth?" Journal of Political Economy 82(6): 1095-1117.

[5] Barro, R. J. (1991). "Economic Growth in a Cross Section of Countries." The Quarterly Journal of Economics 106(2): 407443.

[6] Beaugrand, P., et al. (2002). "The Choice Between External And Domestic Debt In Financing Budget Deficits: The Case Of Central And West African Countries." International Monetary Fund 2(79): 1-30.

[7] Bloomstrom, et al. (1996). "Is Fixed Investment The Key to Economic growth." Quarterly Journal of economics 108: 809842 .

[8] Calero (2008). "Remittances, Liquidity Constraints and Human Capital Investments In Ecuador." World Development. Discussion 3358.

[9] Chenery, H. B. and A. M. Strout (1966). "Foreign Assistance and Economic Development" The American Economic Review 56(4): 679-733.

[10] Diamond, P. A. (1965). "National Debt in a Neoclassical Debt Model." Journal of Political Economy 55(5): 1126-1150.

[11] Faridi, M. Z., Nasim, I and Bashir, F. (2015). "An Analysis of Exploring the Relationship between Foreign Inflows and Sectoral Output of Pakistan" European Journal of Business and Management 7(22): 72-77.
[12] Hameed, A., Ashraf, H., Chaudhary. M. A (2008). "Exteranl Debt and its impact on Economic and business Growth in Pakistan." International Research Journal of Finance and Economics 20: 132-140.

[13] Harbison, H. F. (1962). "Human Resources Development Planning in Modernizing Economies." International Labor Review: 453-458.

[14] Iqbal, A., et al. (2015). "Investigating The Role of External Trade and Extral Debt on Economic Growth of Pakistan." Journal of Bussiness of Studies 11(1): 27-39.

[15] Iqbal, Z. and Sattar, A. (2005). "The Contribution Of Workers' Remittances To Economic Growth In Pakistan." Pakistan Institute of Development Economics. Research Report 187.

[16] Jebran, K., et al. (2016). "Public Debt And Economic Growth In Pakistan: A Reassessment." Pakistan Business Review: 307-324.

[17] Johnson, A. O. (2000). "Human Capital Development and Economic Growth in Nigeria." European Journal of Business and Management 3 (9): 1-11.

[18] Johnson, A. O. (2011). "Human Capital Development and Economic Growth in Nigeria." European Journal of Business and Management 3 (9): 29-38.

[19] Jongwanich, J. (2007). "Remittance Economic Growth and poverty in Developing Asia and the Pacific Countries." UNESCAP. Working Paper No. 7 (1).

[20] Khan, M. and Reinhart. C. M. Sand (1990). "Private Investment and Economics Growth in Developing Countries." World Development 18: 19-27.

[21] Kirkpatrick, C. (2000). "Financial Development, Economic Growth and Poverty Reduction" The Pakistan Development Review 39(4): 363-388.

[22] Kohlchen, E. (2007). "Domestic Vs External Sovereign Debt Servicing: An Empirical Analysis." The University of Warwick: 1-28.

[23] Maana, I., Raphael, O. and Nahashon, M. (2008). "Domestic Debt and the Growth of Nigerian Economy." Annual African Econometric society.

[24] Malik, S., M. K. Hayat and M. U. Hayat. (2010). "External Debt and Economic growth: empirical Evidence from Pakistan." International Research Journal of Finance and Economic 44: 89-97.

[25] Matiti, C. (2013). "The Relationship Between Public Debt And Economic Growth In Kenya." International Academic Journal of Information Sciences and Project Management 1(1): 65-86.

[26] Mincer, J. (1958). "Investment in Human Capital and Personal income Distribution" Journal of Political Economy 66(4): 281-302.

[27] Muhdi and K. Sasaki (2009). "Roles of External and Domestic Debt in Economy: Analysis of a Macroeconometric Model for Indonesia." Interdisciplinary Information Sciences 15(2).

[28] Najid and L. M. Ahmad (2012). "Returns to Education In Developing Countries: A Case Study Of Pakistan." Asian Journal Of Research In Business Economics And Management: 217-222. 
[29] Ogiriki, T. and P. W. Andabai (2014). "Financial Intermediation and Economic Growth in Nigeria, 1988 - 2013: A Vector Error Correction Investigation" Mediterranean Journal of Social Sciences 5(17).

[30] Otani, Ichiro and Villanueva (1996). "Major Determinants of Long Run Growth in LDCs." Finance and Development 26: 41-43.

[31] Patnaik, P. and C. P. Chandrasekhar (1996). "Investment, Exports and Growth: A Cross-Country Analysis." Economic and Political Weekly 31(1): 31-36.

[32] Pesaran, M. H., et al. (2001). "Bounds testing approaches to the analysis of level relationships." Journal of Applied Econometrics 16: 289-326.

[33] Rais and Tanzeela (2010). "Public Debt and Economic Growth in Pakistan. A Time Series Analysis." Academic Research International 2(1): 535-544.

[34] Rais, S. I. and T. Anwar (2012). "Public Debt And Economic Growth In Pakistan: A Time Series Analysis From 1972 To 2010" Academic Research International 2(1).

[35] Schultz, W. T. (1961). "Investment in Human Capital." The American Economic Review 51: 1-17.

[36] Shah, M. H. and S. Pervin (2012). "External Publi C Debt And Economic Growth: Empirical Evidence From Bangladesh, 1974 To 2010" Academic Research International 2(3).
[37] Shahzad, H. and A. Y. Javid (2015). "Impact of Debt on Aggregate Investment and Productivity in Developing Asian Countries." Pakistan Institute of Development Economics 127.

[38] Sheikh, M. R., Faridi, M. Zahir and Tariq, K. (2010). "Domestic Debt and Economic Growth in Pakistan: An Empirical Analysis." Pakistan Journal of Social Sciences 30(2): 373-387.

[39] Singh, S. K. (2014). Public Finance in Theory and Practice. New Dehli ,India, S. Chand \& Company Ltd.

[40] Stark and Lucas. R (1988). "Migration, Remittances and Family Economic Development and Cultural Change." 31(1): 191-196.

[41] Taylor, J. E. (1992). "Remittances and Inequality Reconsidered; Direct, Indirect and International Effects." Journal of Policy Modeling 14(2): 187-208.

[42] Wani, N. U. H. and H. Kabir (2016). "An evaluation of relationship between public debt and economic growth: A study of Afghanistan." Munich Personal Re PEc Archive.

[43] Woodruff, C. and Zenteno, R. M. (2004). "Remittances and Micro Enterprises in Mexico." Graduate School of International Relations and Pacific Studies, University of California.

[44] Young, O. D. (2002). "Stage of Economic Development, Exports, and Economic Growth: An Empirical Investigation." The African Economic and Business Review 3(1): 60-69. 